\title{
PENERAPAN COGNITIVE BEHAVIOR THERAPY (CBT) UNTUK MENINGKATKAN SELF-REGULATION PADA PENGGUNA AMPHETAMINE DI BALAI BESAR REHABILITASI BADAN NARKOTIKA NASIONAL LIDO SUKABUMI
}

\author{
Azka \\ Fakultas Teknik Industri \\ Universitas Islam Jakarta \\ Jl. Balai Rakyat, Utan Kayu, Jakarta - 13120 \\ Email : azkanada@yahoo.com
}

\begin{abstract}
Self-regulation on drug users is the key that they are able to get away from the addiction especially after discharge from rehabilitation. Drugs addict needs self regulation in effort to get away from drugs addiction. In order toimprove self-regulation, researcher had been applying cognitive behavior therapy (CBT). the method used in the study is basic single-case experimental with $A-B-A$ design. The Result of this study is cognitive behavior therapy can improve self-regulation on amphetamine users.
\end{abstract}

Keywords : amphetamine,self regulation,substance dependence, cognitive behavior therapy

\section{Pendahuluan}

Di zaman modern ini, banyak sekali masalah yang terus berkembang di kalangan masyarakat yang belum teratasi ataupun yang belum ditemukan solusinya. Masalah yang ada di kalangan masyarakat ini contohnya, tawuran antar warga atau anakanak sekolah, tindakan asusila baik pada orang dewasa, dan anak-anak, kekerasan rumah tangga, pemakaian serta penyalahgunaan obat-obatan terlarang dan lain-lain. Masalah-masalah yang ada dikalangan masyarakat ini sangat menarik untuk dibahas dan ditemukan solusinya. Seperti yang diberitakan dalam okezone (24/11/2015), Jakarta- salah satu anggota band ternama yaitu RS ditangkap karena kepemilikan ganja, pasalnya ia belum lama keluar dari penjara akibat kasus yang sama, sebelumnya musisi senior FRM pertama kali ditangkap 28 Oktober 2007 saat terjaring razia polisi dia kedapatan lintingan ganja sebanyak 5 gram, kemudian pada 6 Januari 2015 ia tertangkap lagi oleh polisi karena ditemukan barang bukti berupa heroin dan ganja. Artis senior RM juga pernah terlibat kasus penyalahgunaan narkoba, pertama kali ia ditangkap karena kepemilikan sabu-sabu dan dipenjara 9 bulan. Kemudian terangkap lagi di Surabaya pada 13 november 2007, dari hasil penggeledahan didapatkan barang bukti 1,5 ons sabu dan, 3 buah alat hisap (bong), alumunium foil, korek api dan banyak sedotan [20].

Keadaan tersebut merupakan salah satu dari sekian banyak kasus yang berkaitan dengan pemakaian dan penyalahgunaan obat-obatan terlarang. Tidak hanya sekali dilakukan tetapi sampai dua kali kedapatan memakai dan tertangkap, padahal sudah diberikan hukuman.

Hawari (1990) menyatakan bahwa mekanisme terjadinya penyalahgunaan narkoba disebabkan karena adanya interaksi antara faktor-faktor predisposisi (faktor internal kepribadian), faktor kondisi keluarga dan faktor pencetus yang meliputi tingkat kecemasan yang dihayati individu, pengaruh teman kelompok sebaya dan ketersediaan zat itu sendiri. Dinamika setelah terjadinya penyalahgunaan narkoba akan menyebabkan sulitnya penanganan terhadap para penyalahgunaan narkoba dan residen, digambarkan Seevers (dalam Kahfi \& Rosiana, 2013) sebagai berikut : Setiap pengalaman yang menyenangkan ketika memakai narkoba, akan berfungsi sebagai continued positive reinforcement. Dapat ditundanya (untuk sementara waktu) kecemasan yang mereka alami dari tidak 
terpenuhinya kebutuhan, ketika memakai narkoba, akan membuat mereka merasa sejahtera (optimal state of well being). Akibatnya ketergantungan psikologis terhadap reward yang diperoleh dari pengalaman-pengalaman menyenangkan selama memakai narkoba akan menjadi pola tingkah laku terbiasa (a conditioned pattern of behavior). Dinamika ini menunjukkan dengan banyaknya usaha yang dilakukan oleh banyak pihak seperti pusat rehabilitasi, aparat kepolisian, program rawat inap dan lainnya, pada kenyataannya dalam menangani pengguna narkoba yang mau menghentikan kebiasaannya, tetapi dalam kenyataannya masih banyak terjadi relapse (penggunaan narkoba kembali setelah mengikuti masa rehablitasi). Terjadinya relapse terdapat faktor internal dan eksternal individu pada pengguna narkoba itu sendiri, diantaranya; tingkat religiusitas, peranan keluarga dan teman sebaya, kecemasan, sosial ekonomi, dan lain-lain.

Salah satu faktor internal yang berpengaruh pada individu pengguna narkoba yaitu self-regulation, kapasitas untuk self regulation, dapat mengontrol pemikiran dan tindakan untuk kepentingan individu itu sendiri atau untuk memenuhi norma sosial yang ada, pentingnya bagaimana individu terhadap pekerjaan, waktu luang dan hubungan individu terhadap orang lain (Alcock \& Sadava, 2014)

Dalam Kahfi \& Rosiana, 2013 dijelaskan bahwa self-regulation merupakan bagian diri yang berfungsi sebagai salah satu pengendali perilaku, khususnya dalam upaya pemenuhan kebutuhan-kebutuhan, motifmotif dan nilai-nilai yang melekat di dalamnya. Pentingnya self-regulation dalam mencapai sebuah tujuan menjadikan setap manusia mencoba untuk meregulasi dirinya. Berbagai cara dilakaukan individu untuk mencapai tujuannya tersebut. Semakin efektif regulasi diri yang dilakukan maka keberhasilan dalam mencapai tujuan juga akan semakin baik, khususnya pada pengguna narkoba. Dimana apabila individu mempunyai self-regulation yang rendah kemungkinan untuk menggunakan narkoba kembali akan semakin tinggi dan individu yang memiliki self-regulation yang tinggi kemungkinan ia kembali menggunakan barang tersebut juga semakin kecil.

Dari penjelasan di atas peneliti berasumsi bahwa, self regulation adalah salah satu variabel yang diduga dapat mencegah para pengguna narkoba kembali menggunakan barang-barang tersebut (relapse)setelah individu melakukan rehabilitasi.

\section{Metode Penelitian}

Metode penelitian yang digunakan adalah metode penelitian Basic Single-Case Experimental Design. Menurut Phares (dalam Suprapti, 2003), desain satu kasus merupakan perwujudan dari pendekatan perilaku (behavior approach) yang mengutamanakan pengukuran perilaku nyata seperti dianjurkan dalam belajar operan. Peneliti menggunakan A-B-A design, dengan menggunakan desain ini menunjukkan bahwa variabel independen mempengaruhi perilaku, pertama dengan dengan menunjukkan bahwa variabel menyebabkan perilaku sasaran terjadi, kemudian dengan menunjukkan bahwa penghilangan variabel menyebabkan perilaku untuk berhenti.

2.1 Subyek dan Karakteristik Penelitian

Subyek penelitian ini yaitu seseorang amphetamine dependence dengan penggunaan sabu yang memiliki usia 12-20 tahun yang sedang menjalankan program rehabilitasi di $\mathrm{BNN}$, dan bersedia menjadi responden serta melengkapi inform consent, memiliki kriteria self-regulation yang rendah.

\subsection{Metode Pengumpulan Data}

Metode pengumpulan data pada penelitian ini yaitu observasi, wawancara, tes psikologi yang meliputi: tes inteligensi WBIS, tes kepribadian MMPI, BAUM, DAP, HTP dan SSCT, serta menggunakan Self Regulation Questionnaire sebagai prepost test.

\subsection{Metode Analisis Data}

Metode analisis data yang digunakan pada penelitian ini yang sesuai dengan tujuan penelitian yaitu analisi penjodohan pola (pattern matching), membandingkan pola yang didasarkan atas empirik dengan pola yang diprediksikan. Analisis pattern matching dalam penelitian ini adalah 
membandingkan prediksi awal atau asumsi yang akan terjadi dengan fakta sebenarnya di lapangan. Untuk mengetahui hasil dari penerapan terapi CBT untuk meningkatkan self-regulation peneliti menggunakan self regulation questionnaire.

2.4 Waktu dan Tempat Pelaksanaan Penelitian

Penelitian dilakukan dimulai dari tanggan 13 April 2016 sampai 14 Mei 2016 bertempat di Balai Besar Rehabilitasi Badan Narkotika Nasional Lido Sukabumi, Jawa Barat

\section{Analisis Dan Hasil}

Berdasarkan dari hasil pattern matching, terdapat kesesuaian antara temuan kasus dan teori, dimana subyek tidak dapat menentukan tujuan spesifik, orientasi tujuan performansi, efikas diri rendah, tidak ada minat, perencanaan tidak fokus, selfhandicapping, monitoring diri pada hasil, tidak mengevaluasi diri, atribusi kemampuan, reaksi diri negatif, dan tidak adaptif.

Hasilpada intervensi didapatkan, pada pertemuan kelima $\mathrm{F}$ dapat menentukan tujuan spesifik dan minat intrinsik yang ia sukai, Kemudian pertemuan keenam ia sudah mulai orientasi pada penguasaan tujuan yang telah ia tentukan dan dapat meningkatkan keyakinan akan kemampuannya mencapai tujuannya. Pada pertemuan ketujuh ia sudah mulai fokus pada perencanaan mencapai tujuan. Pertemuan kedelapan ia dapat mengetahui apa usaha yang dilakukan untuk meyakinkan diri sendiri bahwa tujuan akan tercapai dan dapat membayangkan keberhasilan setelah proses pemulihan selesai sebagaimana yang telah direncanakan untuk mencapai tujuan. Pertemuan kesembilan ia mulai memonitoring proses yang telah ia lakukan selama intervensi. Pertemuan kesepuluh ia mulai dapat mengevaluasi diri dan pertemuan ke-11 ia menentukan derajat kepuasaan terhadap perilaku yang telah dilakukan setelah tujuan. Pertemuan ke-12 ia mulai melihat faktor-faktor apa saja yang dapat mempengaruhi perubahannya untuk mencapai tujuan. Pertemuan ke-13 ia mulai dapat memberikan kesimpulan mengenai perilaku apa yang akan ditampilkan selanjutnya setelah intervensi selesai.

\section{Pembahasan}

Pada kasus F, self-regulation rendah dikarenakan adanya hambatan perkembangan dimulai ketika ayahnya meninggal dunia, padahal ia sangat dekat dengan ayahnya, ia sangat terpukul semenjak kepergian ayahnya, dan ibunya juga membebaskannya untuk bergaul dan mengambil keputusan dari usia masih anakanak. Ia tidak ingin melanjutkan sekolah ke Sekolah Menengah Pertama, ibunya memperbolehkannya, dan ia bebas bermain/ bergaul di luar rumah. Sehingga kebebasan tersebut membawanya pada pergaulan di luar yang membahayakan untuk anak-anak, terutama apabila tidak dibimbing dengan nasihat orang dewasa. Pada usia remaja ia mengalami identity confusion (kebingungan identitas) yang membawanya ke penggunaan narkoba.

Pada awalnya ia hanya mencoba-coba saja ketika ada narkoba ia hanya mengkonsumsi. Namun sesuai dengan teori classical conditioning sebelum mengenal narkoba ketika ada masalah ia tidak ada keinginan untuk mengkonsumsi narkoba, Namun setelah mengenal narkoba, dan mempunyai masalah, keinginan untuk mengkonsumsi meningkat, sehingga pada saat ia mendapatkan masalah, keinginannnya untuk menggunakan narkoba juga meningkat. Sehingga ia melakukan segala cara hingga tindakan kriminal dilakukan untuk mendapatkan uang dan membeli narkoba.

Dari hasil intervensi yang diberikan CP dengan teknik cognitive behavior therapy dengan problem solving pada $\mathrm{F}$ yang menggunakan amphetamine, didapatkan adanya hasil yang positif. Hal tesebut ditunjukkan dari hasil observasi perilaku yang didapat dan hasil pre-post test yang diberikan.

\section{Kesimpulan}

Gambaran klinis self-regulation pengguna amphetamine pada $\mathrm{F}$ pada teori rendahnya self-regulation memiliki kesamaaan antara teori dan kasus. Pada F terlihat sebelum dilakukan intervensi ia 
belum mempunyai tujuan spesifik dan minat intrinsik, orientasi tujuanpun masih sebatas performansi bukan penguasaan, keyakinan akan kemampuan dirinya juga belum ada. Ia tidak fokus pada perencanaannya, dan tidak dapat menetapkan dengan sungguh-sungguh untuk mengikuti proses pemulihan, ia juga tidak dapat memonitoring dirinya untuk menuju keadaan yang lebih baik. Kemampuannya untuk mengevaluasi dirinya tidak terlihat, ia tidak mampu melihat faktor lingkungan yang dapat mendukung dalam proses pemulihannya. Kepuasan terhadap perilaku tidak sesuai tujuan hanya mengikuti egonya semata. Ia juga tidak dapat memutuskan mengenai perilaku yang akan ditampilkan setelah menjalankan pemulihan.

Dari hasil penerapan terapi cognitive behavior therapy terlihat perubahan pola pikir dan perilakunya walaupun perkembangannya cukup lambat, namun $F$ dapat menerima intervensi dengan baik.

\section{Saran}

\subsection{Saran Teoritis}

Bagi peneliti yang tertarik untuk meneliti tentang penerapan cognitive behavior therapy untuk meningkatkan selfregulation pada pengguna Narkoba khusunya amphetamine perlu mempertimbangkan faktor-faktor yang mempengaruhi self-regulation subyek, sehingga hasil yang didapatkan setelah melakukan intervensi lebih optimal, serta lebih spesifik dalam meningkatkan selfregulation

\section{a. Saran Praktis}

Saran yang praktis yang diberikan kepada subyek yaitu: diharapkan dapat mempertahankan pola pikir dan perilaku dari hasil intervensi, memiliki pertahanan yang baik jika ditawarkan narkoba, menghindari lingkungan pertemanan yang dapat merusak dirinya kembali, dan mempunyai kesibukan yang positif ketika sudah keluar dari rehabilitasi.

\section{Ucapan Terima Kasih}

Penulis mengucapkan terima kasih kepada Universitas Islam Jakarta yang telah memberi dukungan financial terhadap penelitian ini.

\section{DAFTAR PUSTAKA}

[1] Alcock, J., \& Sadava, S. 2014. An Introduction to Sosial Psychology. London: SAGE Publication Ltd.

[2] Berk, \& Laura, E. 1993. Infants, Children, Adolescents. Massachusets: Allyn \& Bacon.

[3] Calhoun, J. F., \& Acocella, J. R. (1990). Psikologi tentang Penyesuaian dan Hubungan Kemanusiaan (3 ed.). (R. Satmoko, Trans.) Semarang: IKIP Press.

[4] Carey, D. J. 2005. A Folow-up psychmetric analysis of the self regulation questionnaire. Psychology of Addicting Behavior, 414-422.

[5] Davison, G. C., Neale, J. M., \& Kring, A. M. 2014. Psikologi Abnormal (9 ed.). (N. Fajar, Trans.) Jakarta: PT Rajagrafindo Persada.

[6] Feist, J. F. 2008. Theories of personality. Yogyakarta: Pustaka Belajar

[7] Feist, J., \& Feist, G. 2001. Theories of Personality (5 ed.). New York: McGraw-Hill Companies.

[8] Fiske, \& Taylor. 1991. Sosial Cognition (2 ed.). New York: McGraw Hill, Inc.

[9] Friedman, H. S., \& Schustack, M. W. (2006). Kepribadian Teori Klasik dan Riset Modern (3 ed.). Jakarta: Erlangga.

[10] Gendolla, G. H., Tops, M., \& Koole, S. L. 2015. Handbook of Biobehavioral Approaches to SelfRegulation. New York: Springer Science.

[11] Harahap, P. 2015. Rubrik. Retrieved November 24, 2015, from Kompasiana: http://www.kompasiana.com/phadli/ju mlah-pengguna-narkoba-diindonesia_553ded8d6ea834b92bf39b3 $\underline{5}$

[12] Hawari, D. 1990. Penyalahgunaan dan Ketergantungan Napza (Narkotika, Alkohol, dan Zat Adiktif Jakarta: FK UI.

[13] Isrizal. 2013. Modul Terapi Perilaku Kognitif (Cognitive Behavioral 
Therapy Manual). Jakarta: Universitas Persada Indonesia Y.A.I.

[14] Kahfi, A. S., \& Rosiana, D. 2013. "Religiousness Islami" dan "Self Regulation" Pada Pengguna Narkoba. Mimbar, 29, 77-84.

[15] King, L. A. 2014. The Science of Psychology an Appreciative View. New York: McGraw Hill

[16] Kusdiyati, S., \& Fahmi, I. 2015. Observasi Psikologi. Bandung: PT Remaja Rosdakarya.

[17] Leary, M. R. 2012. Introduction to Behavioral Research Methods. Canada: Pearson Education, Inc.

[18] Moleong, J. 2004. Metode Penelitian Kualitatif Jakarta: Remaja Rosdakarya.

[19] Neal, D., \& Carey, K. 2005. A follow up psychometric analysis of the selfregulation questionnaire. Psychology Addicting Behavior, 414-422.

[20] Pervin, L. A., Cervone, D., \& John, O. P. 2015. Psikologi Kepribadian Teori \& Penelitian (9 ed.). Jakarta: Prenadamedia Group.
[21] rik. 2015. Retrieved November 25, 2015, from okezone: http://celebrity.okezone.com/read/201 5/11/23/33/1254460/para-artis-inidua-kali-diciduk-karena-narkoba

[22] Sarwono, J. 2006. Metode Penelitian Kuantitatif dan Kualitatif Yogyakarta: Graha Ilmu.

[23] Suprapti, S. M. 2003. Pengantar Psikkologi Klinis. Jakarta: Penerbit Universitas Indonesia.

[24] Susetyo, Y. F., \& Kumara, A. 2012. Orientasi Tujuan, Atribusi Penyebab, dan Belajar Berdasar Regulasi Diri. Jurnal Psikologi, 39, 95-111.

[25] Woolfolk. 2009. Educational Psychology: Active Learning Edition. Yogyakarta: Pustaka Belajar.

[26] Yin, R. K. 2011. Applications of Case Study Research. New York: Sage.

[27] Zimmerman, B. 1989. A Sosial Cognitive View of Self-Regulated Academic Learning. Journal of Educational Psychlogy, 329-339. 